\title{
床反力と人体挙動に基づく パワーアシストシステムのための操作力推定手法の構築
}

\author{
三 好 孝 典* 高 森 和 博* 勝 田 雄 佑* 寺 嶋一 彦*
}

\section{Estimation Method of Operating Force of Human for Power Assisted System Based on Ground Reaction Force and Human Behavior}

Takanori Miyoshi*, Kazuhiro Takamori*, Yusuke Katsuda* and Kazuhiko Terashima*

\begin{abstract}
Recently, many developed countries have begun to experience the problems associated with an aging society. One problem in particular is the growing number of older adults in the labor who suffer from various physical restrictions. Aiming to develop technology to assist these individuals, the novel power assisted system is proposed in this paper. This system estimates the force applied to the object from both the ground reaction force and the human behavior based on the human body dynamics model with 13 links. Then, estimated force is used for the power assistance to help the conveyance of the heavy object. The validity of the model is verified through both simulation and experiment with three tasks by four subjects, and it is shown that our proposed system can be used as a power assisted system.
\end{abstract}

Key Words: Power Assist, Human Body Dynamics Model, Ground Reaction Force

\section{1. 緒}

言

現在，多くの先進国は少子高齢化が進み高齢化社会を迎えて いる，今後は高齢化が進み，2050 年には多くの先進諸国におい て, 高齢化率が $20 \%$ を超えると予想されており, 高齢化が顕著 な国々では高齢化率は $30 \%$ を超えると予想されている $[1]$. こ のため, 今後の先進諸国に扔いて高齢者の就業の確保が重要な 課題となっている. しかし, 高齢者は熟練した技術と豊富な経 験と知識を有しているが, 肉体能力に制約があり就業が困難に なる場合がある。

これらの現状を踏まえ, 山海らの人の表面筋電位を用いたパ ワーアシストスーッ [2] や Kazerooni らの油圧アクチュエータ による下肢パワーアシスト装具 BLEEX [3], 山田らの自動車 組み立てのスキルアシストシステム $[4]$ 等, パワーアシストシ ステムの研究が数多く行われている. パワーアシストシステム は, 人の力や力を加える際の筋電位信号等をセンサにより計測 し，モータ等で人の動作の補助を行うシステムである。このシ ステムによって, 高齢者や力の弱い人への肉体的負担を軽減す ることが望める。

原稿受付 2012 年 11 月 8 日

*豊橋技術科学大学

*Toyohashi University of Technology

口本論文は学術性で評価されました。

ロ J-STAGE では本論文の電子付録として動画が閲覧できます。
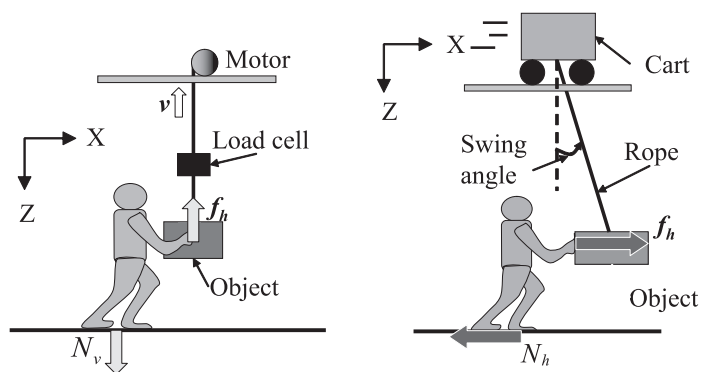

(a) Vertical power assist system (b) Horizontal power assist system

Fig. 1 Schematic illustration of the conventional power assist system

筆者らは, 天井クレーンを用いたパワーアシストの研究を行っ てきた。一般的な天井クレーンの操作は手動スイッチを用いる ため, 荷振れや正確な位置決めが困難であるという久点を有し ているが，パワーアシストを用いて直接荷物を把持することで 手作業に近いスムーズな搬送が可能となる $[5]$. しかしながら 解決すべき課題も残されている，筆者らのシステムの概略図を Fig. 1 に示す．搬送物を直接手に持って操作する従来のシステ ムでは，天井クレーンの装置側にロードセルやレーザーセンサ といった計測センサを取り付け，その值から人が搬送物へ与え る力（以下，操作力）を推定してパワーアシストを行っている. その場合，耐荷重の安全率を見込むと $50[\mathrm{~kg}]$ の搬送物に対して $2,000[\mathrm{~N}]$ の容量のロードセルが必要となり, $\mathrm{S} / \mathrm{N}$ 比の関係から 
検出限界は $5[\mathrm{~N}]$ 程度となってしまうことが確認されている。し たがって $200[\mathrm{~kg}]$ の搬送物に耐えうるロードセルでは, $20[\mathrm{~N}]$ 以上の操作力を加えなければならず，パワーアシストとは言い 難い状況となってしまう。 また, 搬送中には荷振れにより垂直 方向に遠心力が働き，ロードセルにはノイズとして検出されて しまう。例えば，搬送物重量が $60[\mathrm{~kg}]$ の場合，搬送物を搬送す る際の遠心力により $6[\mathrm{~N}]$ 程度の力が検出されることが確認さ れている. 従来研究では, パワーアシスト時の操作力は $20[\mathrm{~N}]$ 程度であり, 重量 $200[\mathrm{~kg}]$ の搬送物ではそのノイズが数十 $[\mathrm{N}]$ となり $\mathrm{S} / \mathrm{N}$ 比が低下するためセンサ信号から精度よく操作力を 推定することは難しい，そこで本稿では, 新たな操作力の推定 方法を提案する.

一般的に搬送物への操作力の計測手法としては, 以下の 5 種 の手法が考えられる。手法 1 : 搬送物に直接力センサを装着し て計測. 手法 2 : 人の手に力センサを装着して計測. 手法 3 : 機 械側にセンサを装着して計測。手法 4 : 筋電位信号や脳波等の 生体信号より操作力を推定. 手法 5 : 垂直抗力とせん断力を含 めた床反力より操作力を推定.

手法 1 は，搬送物に 6 軸力覚センサ等を取り付けるだけです む手法であるが, 搬送物ごとにセンサを着脱する必要があり, 連 続的に作業ができず効率的ではない.

手法 2 に扔いては, 作業をしている人の操作力を計測し, そ の力に応じてパワーアシストを行うため直感的に分かりやすい が, 把持力センサ [6] のようなグローブ型のセンサを用いるこ とが必要である。しかし，人の手は自由度が高いため, グロー ブ型のセンサではパワーアシストシステムにおいて重要となる 力の向きを正確に推定することが難しい. 特に搬送物の位置決 めにおいては，しっかりと搬送物を把持する必要があるために， それぞれの指の向きまで計測する必要が出てくる，その上，計 測装置が複雑で作業を阻害する要素となりえる.

手法 3 は, 従来研究で用いられている手法であり, 前述した ような問題点が存在する。 またこの方法は, ロボットアームタイ プのパワーアシスト装置に一般的に多く用いられている手法で あるが，直接搬送物に触れて作業をするわけではないため，搬 送物に直接触れて作業するタイプのパワーアシストシステムと 比較して操作性が劣るということが報告されている. 例えば, 文 献 [7]では手法 3 に比べて直接把持の方が位置決め誤差は $38 \%$ 減 少し，位置決め時間は $27 \%$ 減少することが示されている.

手法 4 では, 人の活動意思を直接計測できるものの, 筋電位 計測において一般的に用いられる表面電極法は, 関節の屈伸に より皮膚表面の電極と筋瀻維の相対的な位置がずれ, 各試行毎 に信号のばらつきが生じるため, 定量的に扱うことは容易では ない。また, 脳波に扔いては, 脳波によって車椅子等の機器の 制御を行う研究が行われているものの, 多大な訓練が必要であ り正確性にそしい $[8]$.

最後に手法 5 であるが，搬送物に力を加えている手と床反力 を計測する足の間には人体という未知の要素が含まれており, 床 反力から操作力を推定することは難しい. しかし, 床反力から 操作力を推定可能ならば以下のような利点が得られる.

・装置側にセンサがないため，センサの S/N 比から生じる搬 送物の重量制限がない
・手にセンサがないため手を自由に使える

・搬送物を直接手で扱えるため, 正確な位置決めやスムーズ な搬送ができる

・足は手よりも自由度が低く, 計測装置が簡便ですむ

以上の点から本研究では, 操作力を推定する方法として床反 力を用いる方法を提案する.

床反力は, ヒューマノイドロボットや福祉分野の研究で多く 用いられており, 姿勢制御 [9] や下肢に生じる力の推定 [10]に 用いられている。 このような研究の多くでは, 床反力から任意 の目的值, 例えば関節に生じるモーメントや人の姿勢等を推定 するために, 人体の構造や挙動のモデル化を行って抢り, 床反 力から操作力を推定する場合においても人体モデルを用いるこ とが有用であると考えられる。例えば中村らは，人体を 83 自 由度のリンク構造として, 床反力と EMG から逆動力学モデル を用いて筋力の推定を行う, あるいは床反力から各リンクの質 点を求めているが $[11] \sim[13]$, その基本となる理論は人体の構造 をモデル化し，人体の挙動から外力を推定する手法である.

本稿ではその考え方を制御工学的に一歩進め, 推定した全外 力から床反力を差し引くことで人が搬送物に加えた操作力をリ アルタイムに推定する人体動力学モデルを構築するとともに, 推定した操作力の妥当性の検証を行う。ささらに, 推定した操作 力を用いて天井クレーンのパワーアシスト搬送実験を行い, 工 場等に扔ける実用の可能性を探る.

なお，本パワーアシストシステムは健常者（高齢者を含む）に よる重量物の搬送を対象としている。したがって, 従来手法の 操作力が $20[\mathrm{~N}]$ 程度であることと, 数 [N] オーダーの正確な操 作力は推定不可能であると判断し, 操作力の推定精度は $10[\mathrm{~N}]$ 程度を目標とした， $10[\mathrm{~N}]$ 程度の誤差であれば，誤動作したと しても操作者より操作力を加えることによって操作者の意思ど おりに搬送可能で位置決め精度にも影響は少ないと考えられる。

\section{2. 人体動力学モデル}

人体を剛体とし, 究めて静的に近い状況を考えた場合, Fig. 1 に示すように作用反作用の法則より床反力 $N_{v}, N_{h}$ からそのま ま人の力 $F_{h}$ が推定できると考えられる. しかしながら, 人が 運動しながら物体を搬送する場合は慣性力を考慮した上で操作 力を推定する必要がある.

本研究では，人体㧍よび周辺環境を以下のように仮定して人 体モデルの構築を行う.

・骨や関節の軟体部における変形や粘性によるエネルギーの 損失はない

•人体を Fig. 2 のような 13 のリンク, 25 の関節の自由度を 持つ剛体のリンク系とする

-人体に外部から与えられる力は, 床反力, 操作力の反力, 重 力のみ（足と手以外の部位が外部に接触しない）とする

-手の平や指先の接触力はすべて手首に与えられるとし, 手 首から先の手の平や指は考えない

・把持力は操作力に含まない

\section{1 操作力の逐次導出}

剛体座標系原点回りの運動方程式は, Newton-Euler の運動 方程式から次式に整理できる [14]. 


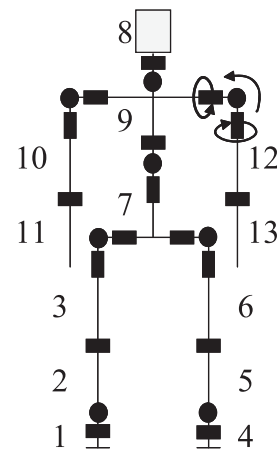

Fig. 2 Model of human body with 13 links

$$
\left[\begin{array}{c}
f \\
\tau
\end{array}\right]=I^{S}\left[\begin{array}{c}
\dot{v}_{o} \\
\dot{\omega}
\end{array}\right]+\left[\begin{array}{cc}
\omega \times & 0 \\
0 & \omega \times
\end{array}\right] I^{S}\left[\begin{array}{c}
v_{o} \\
\omega
\end{array}\right]
$$

ここで, $I^{S}$ は三次元空間の慣性行列， $\boldsymbol{f}$ は重心に作用する 力, $m$ は剛体の質量, $c$ は剛体の重心位置, $\boldsymbol{v}_{\boldsymbol{o}}$ は剛体座標系 原点の並進速度, $\boldsymbol{\tau}$ は重心回りのモーメント, $I$ は重心回りの 慣性テンソル, $\boldsymbol{\omega}$ は角速度, $\boldsymbol{E}$ は $3 \times 3$ の単位行列を表す。ま た, $\boldsymbol{I}^{S}, \boldsymbol{\omega} \times, \boldsymbol{c} \times$ は次式のように定義される.

$$
\begin{gathered}
\boldsymbol{I}^{\boldsymbol{S}} \equiv\left[\begin{array}{ccc}
m \boldsymbol{E} & m(\boldsymbol{c} \times)^{T} \\
m \boldsymbol{c} \times & m \boldsymbol{c} \times(\boldsymbol{c} \times)^{T}+\boldsymbol{I}
\end{array}\right] \\
\boldsymbol{\omega} \times \equiv\left[\begin{array}{ccc}
0 & -\omega_{z} & \omega_{y} \\
\omega_{z} & 0 & -\omega_{x} \\
-\omega_{y} & \omega_{x} & 0
\end{array}\right] \\
\boldsymbol{c} \times \equiv\left[\begin{array}{ccc}
0 & -c_{z} & c_{y} \\
c_{z} & 0 & -c_{x} \\
-c_{y} & c_{x} & 0
\end{array}\right]
\end{gathered}
$$

式（1）を用いることで剛体の並進速度, 角速度から剛体に作 用している力とモーメントを求めることができる.

Fig. 3 に, 空間に存在する剛体リンク機構の第 $j$ リンクに作 用する力とモーメントの関係を示す.ここで, リンク $j$ に作用 するすべての力とモーメントは, 親リンクからの作用 $\boldsymbol{f}_{j}, \boldsymbol{\tau}_{\boldsymbol{j}}$, 子リンクからの反作用 $\boldsymbol{f}_{j+1}, \boldsymbol{\tau}_{j+1}$, リンク $j$ に外部から直接 作用する力とモーメント $f_{j}^{E}, \tau_{j}^{E}$ で表すことができる.ここ で, 本研究では, 人体および周辺環境の仮定として「人体に外 部から与えられる力は, 床反力, 操作力の反力, 重力のみ」と しているため, $f_{j}^{E}$ は重力となり， $\tau_{j}^{E}=0$ となる。 これらを 式（1）を用いて, 剛体の並進速度 $v_{o j}$, 角速度 $\omega_{j}$ で表すと次 のように表される.

$$
\begin{aligned}
{\left[\begin{array}{c}
f_{j+1} \\
\tau_{j+1}
\end{array}\right]=} & I_{j}^{S}\left[\begin{array}{c}
\dot{v}_{o j} \\
\dot{\omega}_{j}
\end{array}\right]+\left[\begin{array}{cc}
\omega_{j} \times & 0 \\
0 & \omega_{j} \times
\end{array}\right] I_{j}^{S}\left[\begin{array}{c}
v_{o j} \\
\omega_{j}
\end{array}\right] \\
& -\left[\begin{array}{c}
f_{j}^{E} \\
0
\end{array}\right]+\left[\begin{array}{c}
f_{j} \\
\tau_{j}
\end{array}\right]
\end{aligned}
$$

ここで, 人の挙動を表す $\boldsymbol{c}, \boldsymbol{v}_{\boldsymbol{o j}}, \boldsymbol{\omega}_{\boldsymbol{j}}, \boldsymbol{v}_{\boldsymbol{o j}}^{\cdot}, \boldsymbol{\omega}_{j}$, 質量 $m_{j}$, 慣性テンソル $I_{j}$ ，および $f_{j}, \tau_{j}$ が既知であるならば， $f_{j+1}$, $\tau_{j+1}$ を求めることができる. したがって, $j=1$ のリンクの

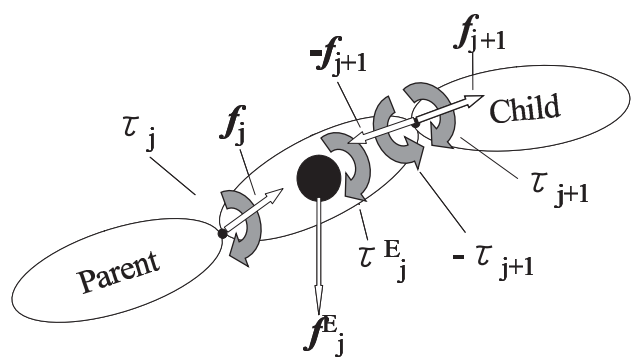

Fig. 3 Force and moment which act on the $j$ link

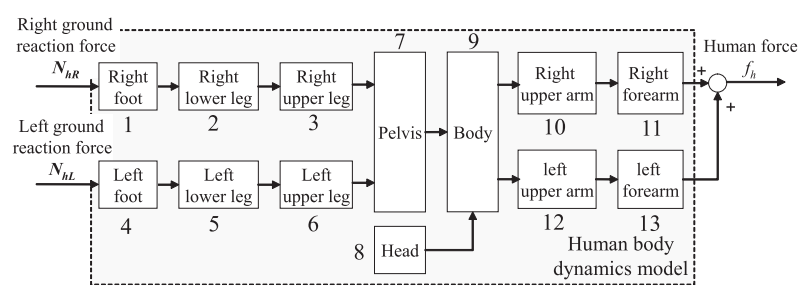

Fig. 4 Sequence employed for the calculation of the applied force

$f_{1}, \tau_{1}$ に床反力を与えることによって， $f_{2}, \tau_{2}$ を導くことが でき, 以後順番に計算を進めることで全関節に生じる力とモー メントを求めることができる.

ただし，本研究モデル化の対象は人体で，パラレルリンク部 が存在する. そこで本研究では, 式（5）を用いて Fig. 4 に示 すように足部より順に計算を進めるが， $f_{j}, \tau_{j}$ もしは $f_{j+1}$, $\tau_{j+1}$ が二つ以上となる両大腿部から下腹部への計算, 胸部・腹 部および頭部から両上腕部への計算では，以下の式 (6), (7) を用いる. また, 各リンク番号と人体部位の対応の定義と, 式 (5), 式（6），(7）における力の入出力は Table 1 に示す.

$$
\begin{aligned}
& {\left[\begin{array}{c}
f_{5} \\
\tau_{5}
\end{array}\right]=I_{4}^{S}\left[\begin{array}{c}
\dot{v}_{o 4} \\
\dot{\omega}_{4}
\end{array}\right]+\left[\begin{array}{cc}
\omega_{4} \times & 0 \\
0 & \omega_{4} \times
\end{array}\right] I_{4}^{S}\left[\begin{array}{c}
v_{o 4} \\
\omega_{4}
\end{array}\right]} \\
& -\left[\begin{array}{c}
f_{4}^{E} \\
0
\end{array}\right]+\left[\begin{array}{l}
f_{4 r} \\
\tau_{4 r}
\end{array}\right]+\left[\begin{array}{l}
f_{4 l} \\
\tau_{4 l}
\end{array}\right] \\
& {\left[\begin{array}{l}
f_{6 r} \\
\tau_{6 r}
\end{array}\right]=\left[\begin{array}{c}
f_{6 l} \\
\tau_{6 l}
\end{array}\right]=\frac{1}{2}\left(I_{5}^{S}\left[\begin{array}{c}
v_{o 5} \\
\dot{\omega}_{5}
\end{array}\right]\right.} \\
& +\left[\begin{array}{cc}
\omega_{5} \times & 0 \\
0 & \omega_{5} \times
\end{array}\right] I_{5}^{S}\left[\begin{array}{c}
v_{o 5} \\
\omega_{5}
\end{array}\right] \\
& \left.-\left[\begin{array}{c}
f_{5}^{E} \\
0
\end{array}\right]+\left[\begin{array}{l}
f_{5 P} \\
\tau_{5 P}
\end{array}\right]+\left[\begin{array}{c}
f_{5 H} \\
\tau_{5 H}
\end{array}\right]\right)
\end{aligned}
$$

本来であれば左右の股関節で骨盤に対する作用点が異なるた め, このような近似は十分とは言えない. しかしながら, 人体 が重量物の搬送中にとる姿勢は，3.2 節で述べるように骨盤を回 転させる運動は少ないと考え, このように近似した。また, 計 算アルゴリズム上最終的に

$$
\left[\begin{array}{l}
f_{6 r} \\
\tau_{6 r}
\end{array}\right]=\left[\begin{array}{l}
f_{6 l} \\
\tau_{6 l}
\end{array}\right]
$$


Table 1 Correspondence of each link

\begin{tabular}{|c|c|c|c|}
\hline Link number & Segment & Input of Forces and Moments $f_{j}, \tau_{j}$ & Output $f_{j+1}, \tau_{j+1}$ \\
\hline 1 & Right foot & $f_{1 r}, \tau_{1 r}$ (GRF applied to the Right foot) & $f_{2 r}, \tau_{2 r}$ \\
\hline 2 & Right lower leg & $f_{2 r}, \tau_{2 r}$ [Right ankle joint] & $f_{3 r}, \tau_{3 r}$ \\
\hline 3 & Right upper leg & $f_{3 r}, \tau_{3 r}$ [Right knee joint] & $f_{4 r}, \tau_{4 r}$ \\
\hline 4 & Left foot & $f_{1 l}, \tau_{1 l}(\mathrm{GRF}$ applied to the Left foot) & $f_{2 l}, \tau_{2 l}$ \\
\hline 5 & Left lower leg & $f_{2 l}, \tau_{2 l}$ [Left ankle joint] & $f_{3 l}, \tau_{3 l}$ [Right hip joint] \\
\hline 6 & Left upper leg & $f_{3 l}, \tau_{3 l}$ [Left knee joint] & $f_{4 l}, \tau_{4 l}$ [Left hip joint] \\
\hline 7 & Pelvis & $f_{4 r}, \quad f_{4 l}, \tau_{4 r}, \tau_{4 l}$ & $f_{5 P}, \tau_{5 P}$ [Hip joint] \\
\hline 8 & Head & None & $f_{5 r}, f_{6 l}, \tau_{6 r}, \tau_{6 l}$ \\
\hline 9 & Body & $f_{5 P}, f_{5 H}, \tau_{5 P}, \tau_{5 H}$ & $f_{7 r}, \tau_{7 r}$ \\
\hline 10 & Right upper arm & $f_{6 r}, \tau_{6 r}$ [Right Shoulder joint] & $f_{7 r}, \tau_{7 r}$ \\
\hline 11 & Right fore arm & $f_{7 r}, \tau_{7 r}$ [Right elbow joint] & $f_{8 r}, \tau_{8 r}$ (Operating force of the Right hand) \\
\hline 12 & Left upper arm & $f_{6 r}, \tau_{6 r}$ [Left Shoulder joint] & $f_{8 r}, \tau_{8 r}$ (Operating force of the Left hand) \\
\hline 13 & Left fore arm & $f_{7 r}, \tau_{7 r}$ [Left elbow joint] &
\end{tabular}

* ( ) is the name of the Force, [ ] is the point at which Forces and Moments are acting

としているが, Fig. 4 に示されるように $f_{h}$ は左右双方の操作 力を加え合わせるため,

$$
\left[\begin{array}{l}
f_{6 r} \\
\tau_{6 r}
\end{array}\right] \neq\left[\begin{array}{l}
f_{6 l} \\
\tau_{6 l}
\end{array}\right]
$$

であっても $f_{h}$ に対する計算結果の影響は小さい.

な拉，式（5）（7）の回転に関する運動方程式の計算は一般 化のために記述しており, 後の第 4,5 章で用いる操作力の並進 力の計算には直接的に用いていない. また, 本研究のように外 力の並進成分だけを求めるのであれば, 文献 [15] のように各り ンクの加速項の重心を足し合わせることで, 極めて簡便に導出 する方法も可能である. この場合, 通常は接触時に打ける未知 の各接触力を推定する問題は染長問題となり, 各リンクにかか る外力の配分を最適化により求めることになるが $[13]$, 本研究 に関しては外力の全体量を求めれば良いので, 最適化を施す必 要はない.

\section{2 リンクパラメータ}

各リンクのパラメータの取得方法を示す。

\section{・リンク質量 : $\boldsymbol{m}_{\boldsymbol{j}}$}

‥R.K.Jensen の人体質量比を用いて作業者の体重より設定 する [16]. リンク質量の同定法についての研究 [11] [12] [17] はあるが, 今回はパワーアシストへの適用が可能であるか 否かを確認することが主目的であるため，一般的な人体体 重比によるリンク質量の設定で実験を行った

・慣性テンソル： $\boldsymbol{I}_{j}$ ‥人体各部の形状に扔いて, 頭部をだ円体, それ以外の 部位を楕円柱と簡略化して推定する

ーリンク長：三次元動作解析装置（後述）により計測する 一楕円の長径，短径：メジャーにより実測.

- 挙動情報（速度，加速度等）: $\boldsymbol{c}_{j}, \boldsymbol{v}_{o j}, \dot{\boldsymbol{v}}_{\boldsymbol{o}}, \boldsymbol{\omega}_{j}, \dot{\boldsymbol{\omega}}_{j}$

… 三次元動作解析装置により計測する

・リンク 1,4 に打ける $f_{1 r}, \tau_{1 r}$ および $f_{1 l}, \tau_{1 l}$ … 床反力計により計測

\section{3. 実験装置および実験条件}

\section{1 実験装置}

上述のモデルにより操作力が正しく推定できるか検証を行っ
た。以下に検証実験の際に使用した装置を示す。

(1) 三次元動作解析装置 $\cdots$ 三次元動作解析装置は, MVN [18] を使用する．MVN はXsens 社製品のスーツタイプの着衣 型モーションキャプチャ装置であり, ジャイロセンサ, 加 速度センサ，地磁気センサから構成されるセンサを用いる ことで, 各リンク両端 17 箇所の挙動を計測する. 取得す る挙動情報はグローバル座標系の挙動であり, 式 $(5) \sim(7)$ ではグローバル座標系での力が計算される，そのため，子 リンクから親リンクに力を足し合わせる際の座標変換は必 要ない. 本研究では荷物を搬送する実験を行うため, 光学 式のモーションキャプチャではマーカが隠れる懸念があり 採用できない，MVN にはその問題はなく，かつ加速度の ドリフトやオフセットを除去し, 各リンクの位置関係を自 動で調整する機能を有することから，これを採用した，本 モデルのリンク数も MVN のセンサ数を考慮して決定した

(2) 床反力 $\cdots$. 床反力計はキスラー式フォースプレート （9286BA）を使用する

(3) 6 軸力覚センサ $\cdots 6$ 軸力覚センサはワコーテック社製 6 軸力覚センサ（WDF-6A200-4-UA）を使用する。モデル から求められた推定値と実測值を比較するために操作力を 計測する

\section{2 実験条件}

天井クレーンを用いた搬送物の搬送動作から, 主要な搬送動 作を選択して実験を行った。ここで搬送動作は, 持ち上げ動作 と移動動作に分割できる。持ち上げ動作に拀いては，1）手を 使って持ち上げる，2）スクワットのように足を伸ばして体ごと 持ち上げる，3）腰を使い上体を起こすようにして持ち上げる 3 手法が考えられる，ただし，3）の動作は腰を痛める可能性があ るため工場内では推奨されていないことから 1)，2）の動作を 選択した。 また, 移動動作においては, 歩行動作が人の主要な 動作として挙げられるため, 搬送物を押しながら歩く動作を選 択した。

実験条件を以下に示す。また，Fig. 5 に実験の状態を示す。

(I) 腕の上下動作 .... 手に搬送物を持ち腰の高さから肩の高さ まで手首を持ち上げ，腰の高さまで下ろす動作を 5 回 （II）スクワット動作 ... 手に搬送物を持ち直立した状態から腰 


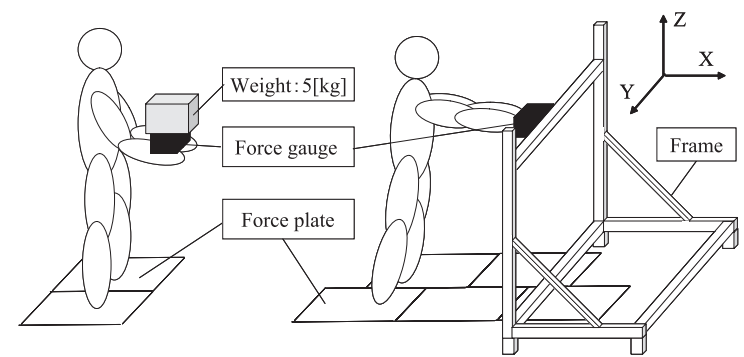

(a) Experimental setup (I), (II) $\quad$ (b) Experimental setup (III)

Fig. 5 Experimental setup

を下ろし，立ち上がるまでを 5 回

(III) 搬送物を押しながら歩く動作 ....力覚センサを押しつつ歩行

各実験では被験者に MVN を着てもらい, 床反力計の上に立 ち, 力覚センサに力を加え実験を行った，力覚センサは, 他の 計測器と軸方向のズレが生じないよう力覚センサの姿勢を一定 に保ち運動するよう被験者に指示を行った。また，各軸の方向 は Fig. 5 に示すとおりである. 被験者のデー夕を以下に示す。

(1) 健常者, 男, 22 歳, $175[\mathrm{~cm}], 80[\mathrm{~kg}]$

(2) 健常者, 男, 22 歳, $169[\mathrm{~cm}], 58[\mathrm{~kg}]$

(3) 健常者, 男, 22 歳, $166[\mathrm{~cm}], 56[\mathrm{~kg}]$

(4) 健常者, 男, 22 歳, $168[\mathrm{~cm}], 58[\mathrm{~kg}]$

なお，本研究は国立大学法人豊橋技術科学大学ヒトを対象と する研究指針の趣旨に基づき, 倫理的配慮のもと, 科学的に適 正に実験研究を実施している.

\section{4. 操作力の推定結果の比較・検証}

\section{1 実験（I）：腕の上下動作}

実験（I）の結果から被験者（1）の結果を抜粋して Fig. 6 に 示す. Fig. 6 において, (a)のグラフは Z 軸方向（高さ方向）の 操作力の推定結果と力覚センサの実測值である。 また，(b)の グラフは Z 軸方向の床反力の值, (c) のグラフは Z 軸方向の操 作力の推定結果と力覚センサの值の誤差を示している. (d)の グラフは手首の Z 軸方向の位置を示している。グラフ (a), (b), (d) より, グラフ (d) の手首の挙動と同じ周期でグラフ (a)の 操作力の推定值と力覚センサの実測值, グラフ (b) の床反力が 変化していることが分かる. また，グラフ (a) とグラフ (c)よ り, 操作力の推定結果と力覚センサの值の変化の傾向も極めて 一致していることが観察できる.

\section{2 実験（II）：スクワット動作}

実験（II）の結果から被験者（1）の結果を抜粋して Fig. 7 に 示す. Fig. 7 において，(a)〜 (c) のグラフは実験（I）と同種の データである. また, (d)のグラフは, 腰の Z 軸方向の位置を 示している. グラフ (a), (b), (d) より, グラフ (d) の腰の挙 動と同じ周期でグラフ (a) の操作力の推定值と力覚センサの実 測值，グラフ (b) の床反力が変化していることが分かる. また, グラフ (a)に拈いては, 操作力の推定值と力覚センサの実測值 は抒㧍むね一致しているが, 局所的に $15[\mathrm{~N}]$ 程度の大きな誤差 が見られる。ここで，グラフ (c), (d) から人が立ち上がるとき (8.5 [s] 前後) に，もしくはしゃがみこむとき（15.5[s] 前後）に

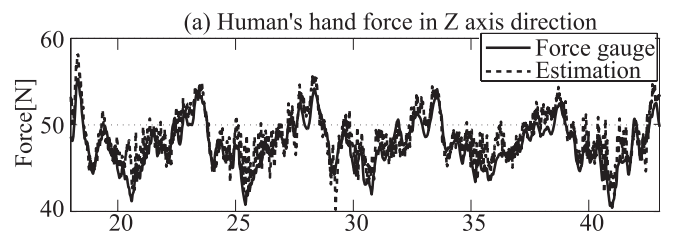

(b) GRF in $\mathrm{Z}$ axis direction
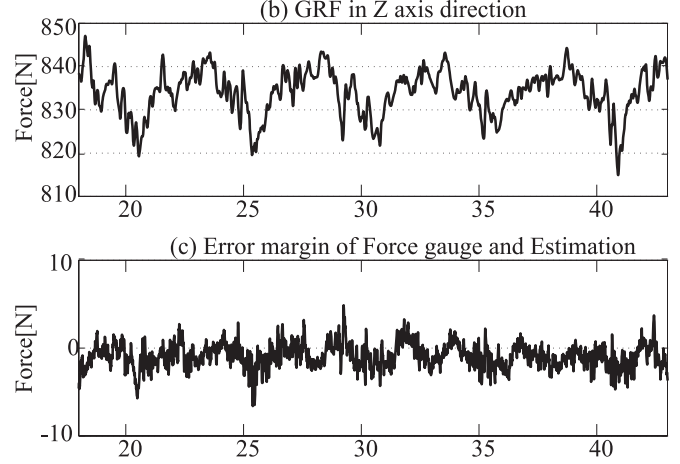

(d) Z-position of wrist

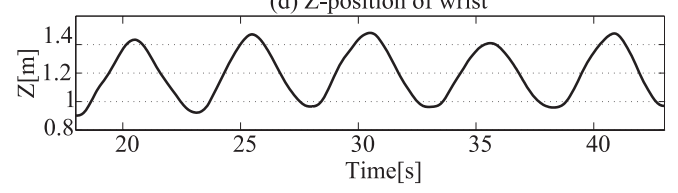

Fig. $6 \mathrm{Z}$ axis direction force of Examinee (1)
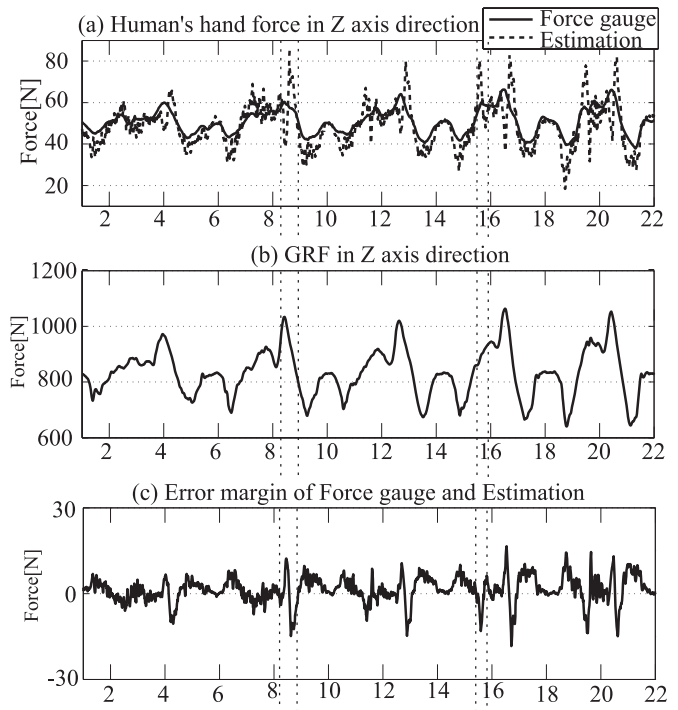

(d) Z-position of waist

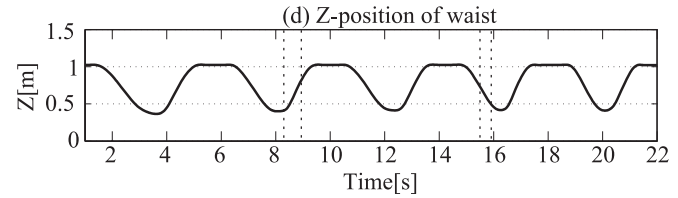

Fig. $7 \quad \mathrm{Z}$ axis direction force of Examinee (1)

誤差が大きく生じていることが観察される。この傾向は, 他の 被験者に扔いても当てはまる。 この誤差の要因の一つとしては 体幹のモデル化の不十分さが挙げられる。 これは, 構築した人 体動力学モデルは, 体幹部における体の屈曲は腰の関節のみで しか現しておらず，背骨の屈曲を正確には表せていないためで ある. しかし，誤差の部分は力の変化の周波数が $3 \sim 4[\mathrm{~Hz}]$ と 

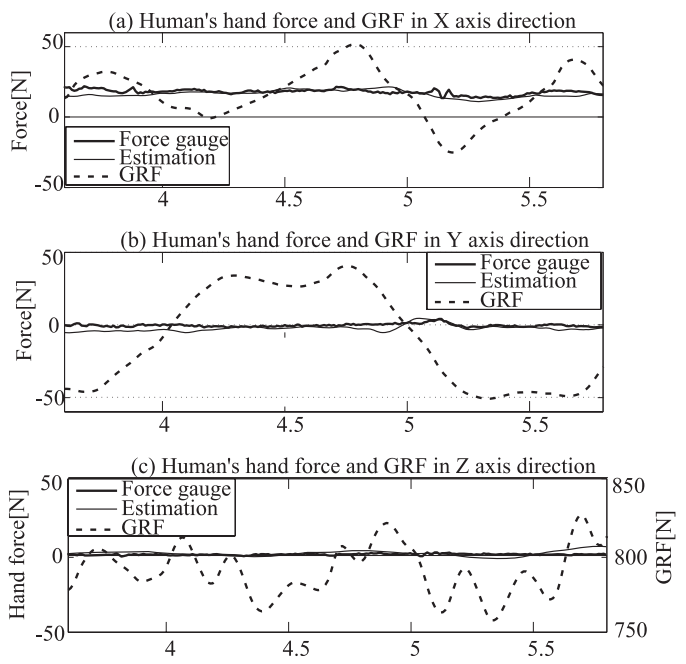

(d) $\mathrm{Z}$ axis position of foo

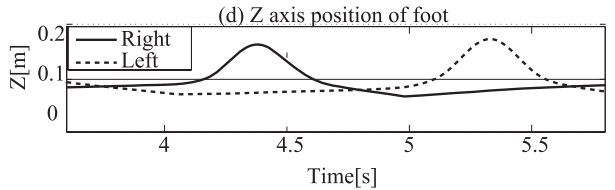

Fig. 8 Behavior of Examinee (1) in the Experiment III

なっており，これは人の走行よりも高い周波数である [19].こ のため, 通常の歩行よりも緩慢な動作である荷物の搬送動作に おいては, フィル夕等で除去することが可能な誤差であると考 えられる。

\section{3 実験（III）：搬送物を押しながら歩く動作}

実験（III）の結果から被験者（1）の結果を抜粋して Fig. 8 に示す. Fig. 8 において, (a)のグラフは X 軸方向（前後方向） の操作力の推定結果, 力覚センサの実測值および床反力值（前 後方向のせん断力）である，また，(b)のグラフはY 軸方向（左 右方向），(c) はZ Z 軸方向（高さ方向）の各力の結果を示してい る. (d) のグラフは両足首の Z 軸方向の位置を示している. (d) のグラフから, $4.2[\mathrm{~s}] \sim 4.6[\mathrm{~s}]$ が左足のみで立脚している状態, $5.1[\mathrm{~s}] \sim 5.6[\mathrm{~s}]$ が右足のみで立脚している状態である. それに応 じて, (b)より体幹の重心が左右に動摇していることが確認で きる. Fig. 8 の各グラフより, 床反力が $80[\mathrm{~N}]$ 程度の変動を生 じているものの, 各操作力には大きな力の変動は表れていない. また，(a)，(b)，(c)に示されるように操作力の推定結果と力覚 センサの実測值は，X 軸方向は約 $20[\mathrm{~N}], \mathrm{Y}$ 軸，Z 軸方向はほ ほ $0[\mathrm{~N}]$ を示している. 加えて, 各軸方向ともに操作力の推定 結果と力覚センサの実測值に大きな誤差はない. 実験（III）に 抒いてはX 軸方向に物体を押して㧍り, 実験条件と合致した結 果が得られている.

\section{4 考察}

実験（I），（II），（III）の結果すべての誤差の 2 乗平均平方根 (RMSE $[\mathrm{N}]$ ) を Table 2 に示す. 誤差の 2 乗平均平方根の值 はどの值も目標推定精度の $10[\mathrm{~N}]$ 内に収まっており, パワーア シストに用いる操作力としては十分の精度であると判断した。

Fig. 6 では床反力の変動は $40[\mathrm{~N}]$ 程度の力であるのに対して, 人の力の変動は半分の $20[\mathrm{~N}]$ 程度であり, Fig. 7 では, 床反力 の変動は $400[\mathrm{~N}]$ 程度であるのに対して, 人の力の変動は 10 分
Table 2 Root mean square of error (RMSE) between the estimated and the measured values

\begin{tabular}{|c|c|c|c|c|}
\hline Examinee & Axis & \multicolumn{3}{|c|}{$\mathrm{R} \mathrm{M} \mathrm{S} \mathrm{E}] \mathrm{N}]$} \\
\cline { 3 - 5 } & & $\operatorname{Exp}(\mathrm{I})$ & $\operatorname{Exp}(\mathrm{II})$ & $\operatorname{Exp}(\mathrm{III})$ \\
\hline \multirow{3}{*}{ Examinee(1) } & $\mathrm{X}$ & 3.2 & 5.1 & 6.5 \\
\cline { 2 - 5 } & $\mathrm{Y}$ & 3.0 & 5.6 & 4.1 \\
\cline { 2 - 5 } & $\mathrm{Z}$ & 1.5 & 6.2 & 5.5 \\
\hline \multirow{3}{*}{ Examinee(2) } & $\mathrm{X}$ & 3.9 & 7.5 & 7.3 \\
\cline { 2 - 5 } & $\mathrm{Y}$ & 3.3 & 8.8 & 6.6 \\
\cline { 2 - 5 } & $\mathrm{Z}$ & 1.5 & 4.2 & 8.5 \\
\hline \multirow{3}{*}{ Examinee(3) } & $\mathrm{X}$ & 2.6 & 3.9 & 5.5 \\
\cline { 2 - 5 } & $\mathrm{Y}$ & 1.6 & 5.3 & 5.5 \\
\cline { 2 - 5 } & $\mathrm{Z}$ & 0.9 & 3.7 & 4.3 \\
\hline \multirow{3}{*}{ Examinee(4) } & $\mathrm{X}$ & 3.9 & 7.4 & 6.6 \\
\cline { 2 - 5 } & $\mathrm{Y}$ & 3.3 & 8.7 & 6.6 \\
\cline { 2 - 5 } & $\mathrm{Z}$ & 1.5 & 4.1 & 5.2 \\
\hline
\end{tabular}

の 1 の $40[\mathrm{~N}]$ 程度である.これは, 床反力の変動の大半は人 体の運動による慣性力によって生じていることを示していると 共に, 我々の提案したシステムで慣性力を正しく推定し, 操作 力のみを分離できていることを示している．同様に Fig. 8 に扮 いても, 床反力はいずれも $80[\mathrm{~N}]$ 程度力の変動であるが, 操作 力の誤差の 2 乗平均平方根の值は $1 / 10$ 程度に抑えられている ことから, 操作力を床反力から推定可能であることが明らかと なった。

\section{5. 天井クレーンでのパワーアシスト実験}

床反力から操作力を正しく推定できることが確認されたため, その操作力を用いて天井クレーン（Fig. 9) のパワーアシスト 搬送する実験を行った，以下に実験条件，実験結果を示す。

\section{1 実験条件}

実験装置は, 三次元動作解析装置 (MVN), 床反力計, 6 軸力覚 センサ, 天井クレーンを用いる。本実験において被験者は MVN を着た状態で, 床反力計の上で行った. 実験状況を Fig. 10 に 示す。ここで, 座標軸は天井クレーンに合わせ被験者の体の左右 方向が $\mathrm{X}$ 軸，進行方向が $\mathrm{Y}$ 軸，高さ方向が $\mathrm{Z}$ 軸とする。 また， 搬送物の重量は $60[\mathrm{~kg}]$ である。搬送物の位置について，X，Y 軸方向はエンコーダ值から算出したカートの位置，Z 軸方向は モータがカートに備え付けられており搬送物の高さである。搬 送物は地面から離れた状態から開始し，位置は初期位置を 0 と する。

操作力推定手法によるパワーアシストシステムのブロック線図 をFig. 11 に示す. ここで, 操作力の推定值から天井クレーンの モー夕の指令電圧への変換に際して, 操作力の誤差の除去のため に $5[\mathrm{~Hz}]$ のローパスフィルタを設け，ゲインは $0.006[(\mathrm{~m} / \mathrm{s}) / \mathrm{N}]$ とした。また，実験（2）では $25[\mathrm{~N}]$ の不感帯を設けた。ロー パスフィルタは, 力の変化が $3 \sim 4[\mathrm{~Hz}]$, 歩行の周波数が 1 $3[\mathrm{~Hz}][19]$ であることから $5[\mathrm{~Hz}]$ に設定した．ゲインは，操作 者の感覚で負担にならないと感じられるまで大きく設定した． 不感帯は, 搬送動作以外で天井クレーンが動作しないように設 定した。

実験（1）では，被験者を搬送物の $\mathrm{Y}$ 軸方向に立たせ，X，Z 軸方向の搬送を不感帯を設けないで行った，搬送物には操作力 の真值を計測するために力覚センサを取り付け，被験者は手で 


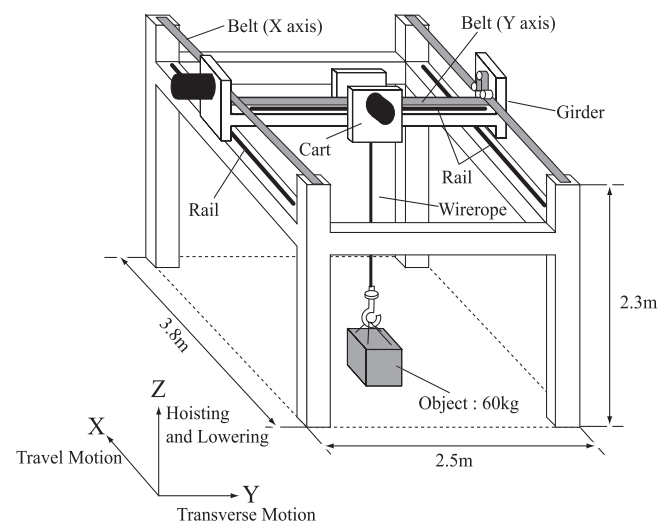

Fig. 9 3-D Transport crane system

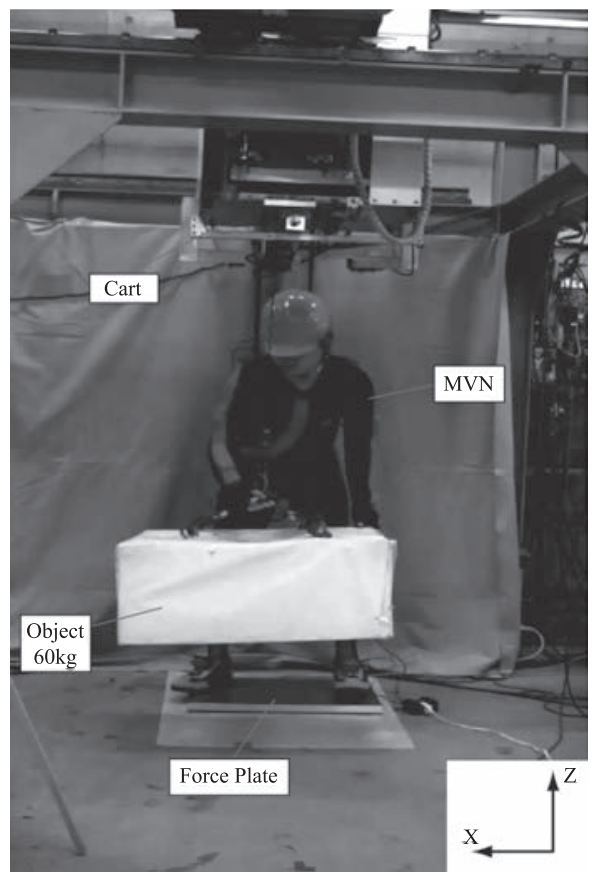

Fig. 10 Experimental setup of the power assisted crane system

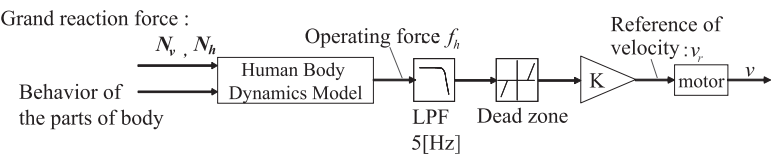

Fig. 11 The block diagram of the power assist system

力覚センサに力を加えることで操作を行った，力覚センサは，他 の計測器と軸方向のズレが生じないよう力覚センサの姿勢を一 定に保ち運動するよう被験者に指示を行った。実験（2）では， 推定誤差を考慮し不感帯 $25[\mathrm{~N}]$ を設け，搬送動作以外で天井ク レーンが動作しないことを示すために，被験者には搬送動作の 前に床反力計の上でスクワットを 2 回と体を左右に摇らす動作 を 2 往復するよう指示を行った。 以下に被験者情報を示す.

- 実験 (1) : 健常者, 男, 23 歳, $168[\mathrm{~cm}], 59[\mathrm{~kg}]$

- 実験 (2) : 健常者, 男, 24 歳, $175[\mathrm{~cm}], 80[\mathrm{~kg}]$

5.2 実験（1）：実験結果

実験（1）の結果を Fig. 12 に示す。ここでグラフの (a), (c)

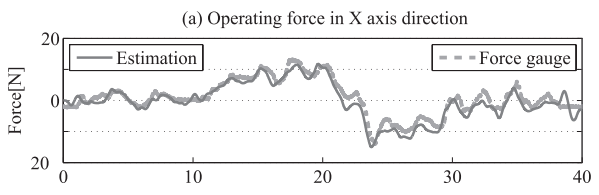

(b) Position in $\mathrm{X}$ axis direction

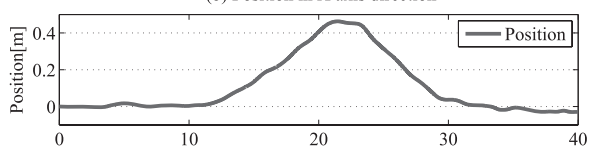

(c) Operating force in $\mathrm{Z}$ axis direction
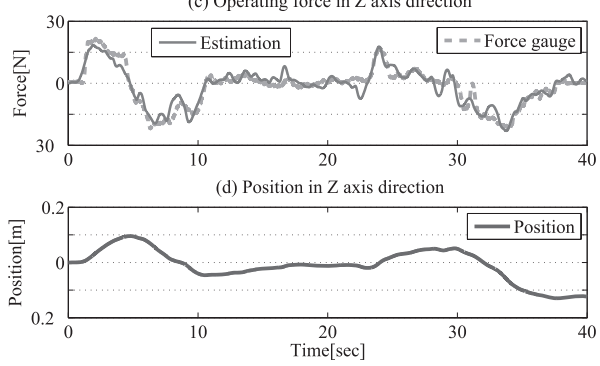

Fig. 12 Experimental result of fundamental work
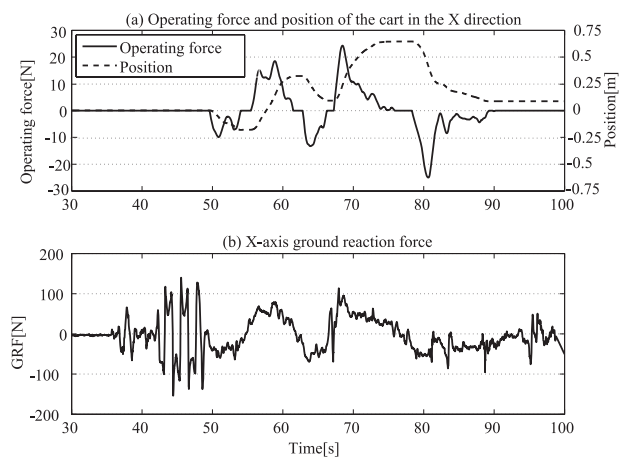

Fig. 13 Experimental results of the X-axis direction

は, $\mathrm{X}, \mathrm{Z}$ 軸方向の操作力の推定值と力覚センサによる計測值で ある。グラフの $(\mathrm{b}),(\mathrm{d})$ は， $\mathrm{X}, \mathrm{Z}$ 軸方向搬送物の位置である.

グラフの (a), (c)より, 推定した操作力が実際の操作力と一 致していることが分かる. (a)のX 軸方向では $10[\mathrm{~N}]$ 程度, (b) の $\mathrm{Z}$ 軸方向では $15[\mathrm{~N}]$ 程度の力が計測されている. またグラフ の (b), (d) より, 推定された操作力に応じて重量物の搬送が行 われていることが分かる.これにより推定された操作力を用い て, $15[\mathrm{~N}]$ 程度の操作力で $60[\mathrm{~kg}]$ の重量物をパワーアシストで きることが示された

不感帯を設けていないため, 推定誤差により操作者が力を加 えている方向とは違う方向に天井クレーンが動く瞬間が感じら れた。 ただ，推定誤差による天井クレーンの動きはわずかなも のであり, 若干の力でその動きを打ち消すことができため, 操 作性に問題はなく操作者の意思どおりに搬送を行うことが可能 であることが確認された

\section{3 実験 $(2)$ : 実験結果}

実験（2）の結果を Fig. 13～Fig. 15 に示す.ここで, Fig. 13 は X 軸方向, Fig. 14 は Y 軸方向, Fig. 15 がZ 軸方向の結果で ある. 各グラフの (b) は実験中の床反力の值を示しており，ま た，各グラフの (b) において, $38[\mathrm{~s}] \sim 41[\mathrm{~s}]$ までがスクワット 

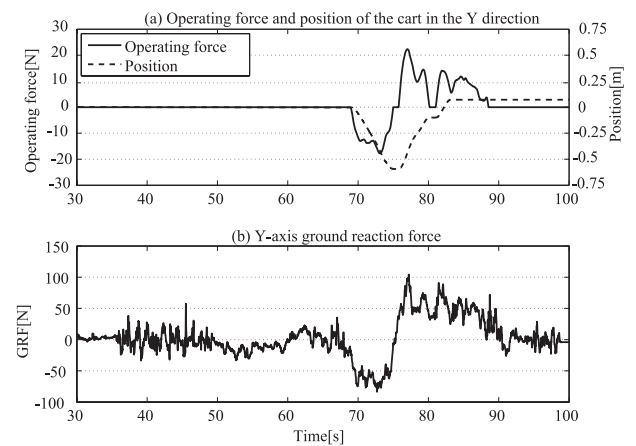

Fig. 14 Experimental results of the $\mathrm{Y}$-axis direction
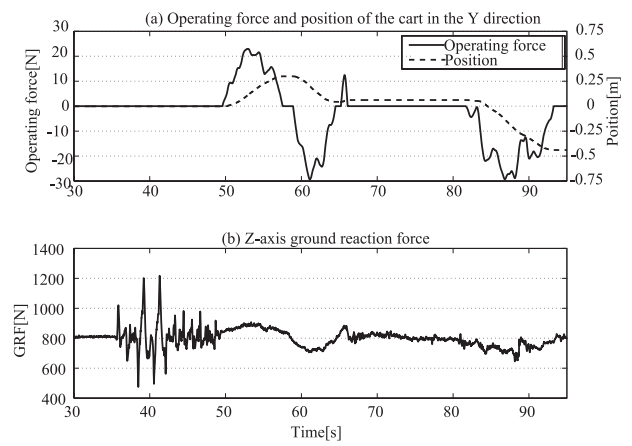

Fig. 15 Experimental results of the Z-axis direction

動作, $41[\mathrm{~s}] \sim 49[\mathrm{~s}]$ までが体を左右に摇らす動作, $49[\mathrm{~s}]$ 以降が 搬送動作である。

各グラフの (a) より, 操作力に応じて天井クレーンが動作を 行っていることが分かる. また，グラフ (a)，(b)の $38[\mathrm{~s}] \sim 49[\mathrm{~s}]$ より, 搬送動作以外の動作に扔いては天井クレーンは動作しな いことが確認できる．以上より本手法を用いることで床反力か ら操作力を推定し, その操作力を用いてパワーアシストを行う ことができることが示された.

\section{6. 結}

言

本研究では, 垂直抗力とせん断力を含めた床反力から人体の 慣性力を推定一分離し, 外部環境に与える操作力を推定できるこ とを確認した。 また, 推定した操作力を用いて天井クレーンの パワーアシスト搬送が可能であることを確認した，具体的には， 1）床反力と人体の挙動（速度, 加速度等）から操作力を推定す る人体動力学モデルを構築し，2）荷物の搬送作業を想定した実 験に扔いて操作力が $10[\mathrm{~N}]$ 以内の精度で，3）人体の挙動によ らずパワーアシスト搬送を行えることを確認した。

今後は, 本手法の有用性を確認するために従来のパワーアシ スト手法との比較を行うとともに, コントローラの適切な設計 により搬送後の残留振動を抑制することを試みる。 さらに, 被 験者ごとの体型によるリンク質量のばらつきが操作力推定に与 える影響について検討を行い，任意の被験者に対して所定の精 度内に納まる推定が可能であるか評価する予定である。 また, 現 在の手法では全身 17 箇所の位置, 速度, 加速度の情報が必要 であるため，実用化には困難が予想される，従って，センサの 数を削減した上で正しい操作力の推定が行えるアルゴリズムの
構築を行う予定である. 加えて, 現状では床反力計が作業空間 全面に必要となるが, 現実問題として不可能であるため, 靴底 に装着できるウェアラブルで安価な床反力計測センサの開発を 行っている. 将来的にヘルメット, 両腕のリストバンド, 腰の ベルト, 靴などに装着されたセンサのみで操作力の推定を可能 にすることを目標としている．

謝 辞 本研究は JSPS 科研費 21560239 の助成を受けたも のです.

\section{参 考 文 献}

[1] 国立社会保障 - 人口問題研究所：人口統計資料, 2010.

[2] S. Lee and Y. Sankai: "Power Assist Control for Walking Aid with HAL-3 Based on EMG and Impedance Adjustment around Knee Joint," IEEE/RSJ International Conference on Intelligent Robots and Systems, pp.1499-1504, 2002.

[3] A.B. Zoss, H. Kazerooni and A. Chu: "Biomechanical design of the Berkeley lower extremity exoskeleton (BLEEX)," IEEE/ASME Transactions on Mechatronics, vol.11, issue 2, pp.128-138, 2006.

[4] Y. Yamada, H. Konosu, T. Morizono and Y. Umetani: "Proposal of Skill-Assist: A System of Assisting Human Workers by Reflecting Their Skills in Positioning Tasks," Proc. IEEE Int. Conf. on System, Man and Cybernetics, pp.(IV)11-(IV)16, 1999.

[5] 三好孝典, 寺嶋一彦, 鈴木裕一：“天井クレーンにおけるパワーア シストシステムの構築”, 日本機械学会論文集 C, vol.70, no.696, pp.2427-2434, 2004.

[6] 関善一, 下条誠, 佐藤滋, 高橋昭彦: “高柔軟性を持つ把持圧分布セン サの開発”, 計測自動制御学会論文集, vol.31, no.9, pp.1528-1530, 2004.

[7] A. Niinuma, T. Miyoshi and Y. Miyashita: "Evaluation of Effectiveness of a Power-Assisted Wire Suspension System Compared to Conventional Machine," IEEE ICMA, pp.369-374, 2009.

[ 8 ] 田中一男：“電動車椅子の脳動制御”, 日本機械学會誌, vol.111, no.1080, pp.927-929, 2008.

[ 9 ] S. Ito, T. Nishigaki and H. Kawasaki: "Standing posture control in constant force field based on ground reaction force," $\mathrm{T}$. SICE, vol.38, no.1, pp.79-86, 2002.

[10] P.A. Oakley: Changes in Three-dimensional Knee Kinematics and Kinetics within Nonnative Gait Speeds, A thesis submitted to the School of Physical and Health Education in conformity with the requirements for the degree of Master of Science, 2000.

[11] G. Venture, K. Ayusawa and Y. Nakamura: "Motion Capture Based Identification of The Human Body Inertial Parameters," IEEE/EMBS Int. Conf. on Engineering in Medicine and Biology, pp.4575-4578, 2008.

[12] M. Hayashibe, G. Venture, K. Ayusawa and Y. Nakamura: "Muscle Strength and Mass Distribution Identification Toward Subject-Specific Musculoskeletal Modeling," IROS 2011, pp.3701-3707, 2011.

[13] K. Yamane, Y. Fujita and Y. Nakamura: "Estimation of Physically Valid Somatosensory Information," IEEE ICRA, pp.26242630,2005

[14] 梶尾秀司：ヒューマノイドロボット.オーム社, 2005.

[15] 杉原知道, 中村仁彦： “時間二重外乱吸収法に基づくヒューマノイド ロボットの全身協調運動制御”, 日本ロボット学会誌, vol.24 no.1, pp.64-73, 2006.

[16] R.K. Jensen: "Changes in segment inertia proportions between 4 and 20 years," J. Biomechanics, vol.22, pp.529-536, 1989.

[17] 鮎澤光, ベンチャー・ジェンチャン, 山本江, 中村仁彦: “床反力計 測に基づくヒューマノイドの全身力学パラメータの同定”, 第 13 回 ロボティクスシンポジア予稿集, 2008.

[18] Xsens MVN : Inertial Motion Capture - Xsens, http://www. 
xsens.com/en/general/mvn（2011/10/18 アクセス）

[19] 酒田信親, 興梠正克, 大隈隆史, 蔵田武志 : “インタラクティブジョ
ギングへの応用”, ヒューマンインターフェイスシンポジウム 2005 , pp.459-462, 2005.
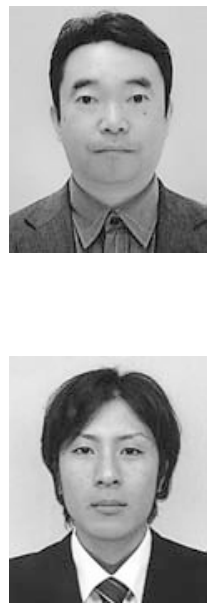

三好孝典（Takanori Miyoshi）

1989 年 3 月大阪大学電気工学科卒業, ローランド ディー。ジー（株）入社. 2001 年 3 月豊橋技術科 学大学博士後期課程電子情報工学専攻修了. 2002 年 4 月豊橋技術科学大学生産システム工学系講師。 現在同大学機械工学系准教授. 計測自動制御学会, 日本機械学会, IEEE 等の会員. 博士 (工学).

(日本ロボット学会正会員)

\section{勝田雄佑（Yusuke Katsuda）}

2010 年 3 月豊田工業高等専門学校機械工学科卒業, 2012 年 3 月豊橋技術科学大学生産システム工学科 卒業. 2012 年 4 月同大学大学院機械工学専攻進学. 人体運動学に興味を持つ。

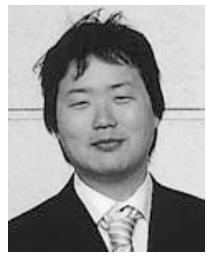

高森和博（Kazuhiro Takamori）

2010 年 3 月豊橋技術科学大学生産システム工学科 卒業. 2012 年 3 月同大学大学院工学部機械工学専 攻修士課程修了。現在凸版印刷株式会社に勤務。福 祉ロボットに興味を持つ

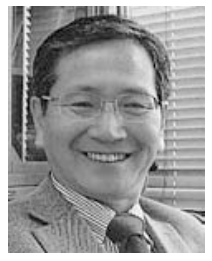

寺嶋一彦 (Kazuhiko Terashima)

1981 年京都大学大学院工学研究科博士後期課程修 了. 1982 年豊橋技術科学大学工学部生産システム 工学系助手. 講師, 助教授を経て 1994 年同大学教 授. システム制御情報学会, 日本機械学会, 日本鋳 造工学会, IEEE 等の会員. 工学博士.

（日本ロボット学会正会員） 